\title{
THE ECONOMIC ASPECTS OF SOLAR ENERGY PRODUCTION BY HOUSEHOLDS IN UKRAINE
}

\section{Oleksandra Mandych, $\mathrm{PhD}^{1}$; Liliia Prokopchuk, $\mathrm{PhD}^{2}$; Arkadii Mykytas, $\mathrm{PhD}^{3}$}

${ }^{1}$ Educational and Scientific Institute of Business and Management, Kharkiv National Technical University of Agriculture

${ }^{2}$ Faculty of Economics, State Agrarian and Engineering University in Podilya

${ }^{3}$ Educational and Scientific Institute of Mechanotronics and Management Systems, Kharkiv National Technical University of Agriculture

\begin{abstract}
In recent decades considerable attention has been paid to alternative and renewable energy. Among the alternative sources, the sun's energy is most appealing. Therefore, the development of solar energy, in the long run, is one of the top priorities. In practice, there are numerous barriers to the growth of the solar energy market. First of all, economic: fairly high prices for solar systems and payback period; the absence of working capital from manufacturing enterprises, the absence of specific mechanisms for stimulating production in the form of subsidies, tax exemptions, preferential tariff policies, etc. Therefore, research into the development of solar energy, as a real tool for a comprehensive solution to economic and environmental problems, is becoming increasingly relevant. The paper considers the energy policy of the use of renewable energy sources in rural areas. The theoretically feasible and technically achievable potential of solar energy in the territory of Ukraine was characterized. It was noted that the sun is the most affordable supplier of energy on earth today. The use of solar radiation is expedient for the development of thermal and electric energy and is possible throughout the territory of Ukraine. The dynamics of the commissioning of solar power plants by private households was analysed. The attention is focused on the application of the 'green' tariff, which stimulates the increase in the number of solar projects implemented in households. A financial model of private households of choosing a solar power plant option was proposed. The problems were identified and the possibilities of using solar energy for ensuring energy independence of households and profit generation were assessed. The forecast for the development of solar energy of the period up to 2020 was made.
\end{abstract}

Keywords: solar power, electricity, household electric energy, solar panels, bioeconomics JEL code: $D 1$

\section{INTRODUCTION}

The current development of the world economy is inextricably linked with the growth of energy produc- tion. The most important problem facing energy is the sources of its supply. Today it is important to carry out scientific research, which should be directed to a quick and effective solution to existing problems.

\footnotetext{
${ }^{1}$ Corresponding author: Alchevskykh 44, 61002 Kharkiv, Ukraine, Ol.mandych@gmail.com, +38 (050) 4843130

${ }^{2}$ Corresponding author: Schevchenko 13, 32300 Kamianets-Podilskyi, Ukraine, prokopchuklm@gmail.com, +38 (096) 0956490

${ }^{3}$ Corresponding author: Alchevskykh 44, 61002 Kharkiv, Ukraine, Arkadiimykytas@ukr.net, +38 (050) 4069999
} 
The most promising source of electricity is the energy of the sun. One can get this energy permanently, for free and anywhere in the world. At the same time, the behaviour of the sun is more predictable than other meteorological factors. Modern technologies allow to use this potential with sufficiently high efficiency.

The most widespread use of solar energy has been found in heat supply systems. They serve for hot water supply, heating and other needs, which significantly reduces the use of traditional fuel resources. The current trend is the rapid expansion of the use of solar power for both centralized power generation at solar power plants and in individual electricity supply systems for public and private buildings (Plachkov et al., 2013).

The purpose of the study is to assess the state of development of solar energy in Ukraine and the prospects of its use in the energy supply system of private households.

\section{THEORETICAL BACKGROUND}

Climate change, population growth, environmental pollution, resource scarcity have led to the need to find and develop modern, renewable and sustainable technologies. Bioeconomy, which arose at the junction of ecology and economics, explores the interaction of man and nature, which takes as a basis for the introduction into human activities of biotechnology, using renewable bioenergy for the production of effective products, contributing to the improvement of the entire life of society as a whole. An important component of research is the use of energy based on renewable raw materials (Odintsova, 2014).

Solar power is one of the perspective and environmentally friendly areas for the development and implementation of renewable energy in Ukraine. The development of solar energy is not only a factor in reducing the energy dependence of Ukrainian households from monopolists, but it also has a significant impact on the balance of prices in the energy market of the country (Chornyy et al., 2016).

In the wider solar power sector, two main directions can be distinguished: solar thermal power that uses solar energy to generate heat, and solar power, which uses solar energy to generate electricity. In countries where there is a high level of solar energy development, there are corresponding state programs that provide favourable conditions, including economic ones, for its use and development (Plachkov et al., 2013).

Today, households can install a private solar power plant with a capacity of up to $30 \mathrm{~kW}$. This opportunity has come about due to the developed in conjunction with the State Department of Energy Efficiency and the adopted Law of Ukraine in 2015. Under this Law, the wholesale electricity market of Ukraine in each accounting period is obliged to purchase from entities subject to the green tariff and to carry out full payment for the cost of electric energy produced at the objects of electric power from alternative sources (Law of Ukraine No 514-19).

\section{MATERIALS AND METHODS}

1. The following documents and materials were used to conduct research on the state of development of solar energy in Ukraine: materials I.V. Plachkov Power Engineering: History, Present and Future, Scientific and Cognitive Edition 2013; of the State Energy Efficiency of Ukraine; Agroexpert; Law of Ukraine No 514-19.

2 . In the process of collecting materials that characterize the state of development of solar energy in households in Ukraine, the method of statistical observation was used to collect the primary statistical material through the registration of facts.

To analyse the totality of the obtained materials, the method of grouping the indicators into homogeneous groups was used.

To present the results of the study were tabular, graphical, calculation methods that allowed to analyse the dynamics of solar energy development for the period 2014-2017 years. The simulation method was used to construct a financial model of the solar power plant of a private household. The forecasting method allowed, using the Excel spreadsheet editor, to use the correlation analysis to calculate the forecasted indicators for the installation of solar power stations in private households for 2018-2020. 


\section{RESULTS AND DISCUSSION}

An important role in human life is played by the energy of the sun, because it is the most affordable source of energy on earth. It is solar power that has the greatest impact on energy markets because of its share in the structure of the cost of 'green' electricity.

Theoretically, the potential energy of the sun in Ukraine is annually 63.01 tonnes of oil equivalent, technically achievable is annually 29.63 tonnes of oil equivalent, or annually $33.77 \mathrm{kWh}$. For the development of thermal and electric energy, the most expedient is the use of solar radiation, which is available throughout the territory of Ukraine. From the ecological point of view, solar power may have very limited constraints in its implementation as it has no significant negative environmental impact. Regarding social characteristics, it should be noted that the quantitative forecasting of the creation of additional jobs is about 3.46 thousand people The dynamics of solar power generation is the largest among renewable energy sources in Ukraine, and there is a tendency to increase the capacity of solar power plants annually. At the same time, the average number of hours of work of stations at full capacity in recent years has decreased to 928 hours per year, which corresponds to the utilization rate of installed capacity at $10.6 \%$ (Kucher et al., 2017).

For partial electricity provision, private sector residents use photoelectric elements that are located on the roof of the house. For the production of solar power, households can choose power plants of the required capacity. To make a decision on choosing a variant of a solar power plant, a financial model for private households was presented (Fig. 1).

Ukraine continues to increase the potential of renewable energy. Over 2016, more than 700 solar homes with a capacity of less than $100 \mathrm{~kW}$ were built, and their total number exceeded 1,000 installations. Especially solar panels and batteries are in demand among farmers and suburban residents, since this equipment allows you to generate energy for own use, and under the Green Tariff programme to sell part of the energy. Therefore, an increase in the number of solar power stations in this sector is justified and profitable (Prel.prom, 2017).

Over the past four years, 3,010 private households in Ukraine have installed solar power plants with a total capacity of $51 \mathrm{MW}$. It is about 2 thousand families, switched to 'clean' electricity by the end of 2017

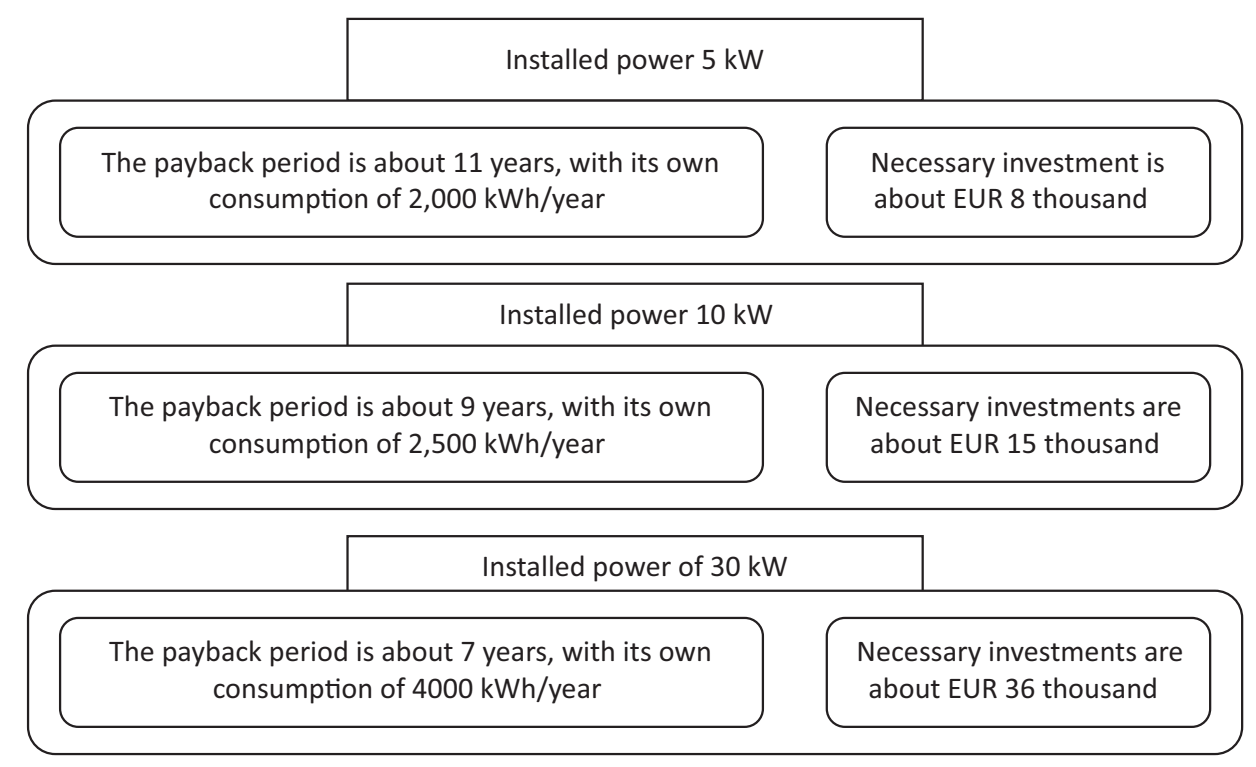

Figure 1. Typical financial model of SES of a private household Source: State Energy Efficiency of Ukraine (2014). 


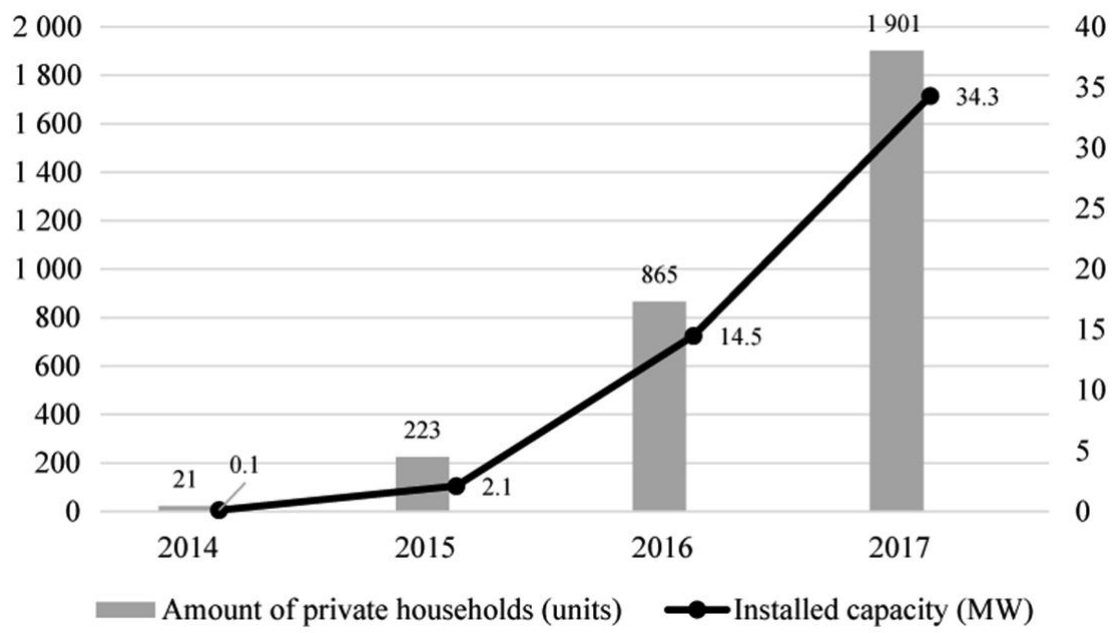

Figure 2. Dynamics installation of solar electrical installations for private households in the years 2014-2017 Source: State Energy Efficiency of Ukraine - 2170 (2018).

(Fig. 2). Over the years, nearly EUR 52 million have been invested by private households in the installation of solar panels. It should be noted that households that installed in 2017 stations with a capacity of up to $30 \mathrm{~kW}$ could by 2,030 sell electricity at a rate of EUR cents 18.09 per $1 \mathrm{kWh}$. Due to the established 'green' tariff for solar power, the number of implemented projects for the installation of domestic solar power plants is increasing (State Energy Efficiency of Ukraine - 2170, 2018).

According to experts, the installation of solar power stations with a capacity of up to $30 \mathrm{~kW}$ makes it possible to earn on sale of 'solar power' UAH 20 -25 thousand in a month. The ability to sell surplus generated 'clean' electricity also stimulates households to rational energy consumption: in particular, install LED lighting, purchase electrical equipment with the highest energy efficiency class, etc. As far as solar power stations are concerned, this sector is also actively developing. As of the end of the first quarter of 2018 Ukraine has installed 1,534 MW of renewable power. Of these, $841 \mathrm{MW}$ is a solar power plant, which is $54.8 \%$ (Government portal, 2018).

It should be noted that for the wide introduction of both heat and power equipment and photovoltaic equipment, the potential of solar energy use in Ukraine is quite high. The average annual amount of total solar energy entering the $1 \mathrm{~km}^{2}$ territory of Ukraine is almost $1,070 \mathrm{kWh}$ in the northern part of the country and $1,400 \mathrm{kWh}$ in the southern regions. It is able to provide savings of up to 6 million tonnes of conventional fuel per year (Agroexpert, 2016).

The forecast of the potential of development of this sector of the electric power industry for the period until 2020 was made based on the study of the state of installation of solar power plants in private households for the period 2014-2017 (Table 1). Using the Excel spreadsheet editor, a linear trend

Table 1. Dynamics of installation of solar power plants by private households

\begin{tabular}{|l|c|c|c|c|c|c|c|}
\hline Indicators & 2014 & 2015 & 2016 & 2017 & 2018 & 2019 & 2020 \\
\hline Amount of private households, units & 21 & 223 & 865 & 1901 & $\times$ & $\times$ & $\times$ \\
\hline Trend line & -189.8 & 438.4 & 1066.6 & 1694.8 & 2323.0 & 2951.2 & 3579.4 \\
\hline
\end{tabular}

Source: calculated by the author. 
graph was obtained that illustrates the relationship between periods and number of installed solar power plants and the determination coefficient $\left(\mathrm{R}^{2}\right)$, which was calculated automatically. On the graph presented $\mathrm{R}^{2}=0.919$, which classifies the connection between the values as high, that is, the constructed model was adequate to the real data (Fig. 3).

Taking into account the obtained trend equation $y=628.2 x-818$ predicted indicators of the installation of solar power plants in private households for 2018-2020 were calculated, according to which the status of their coverage in 2018 will be at 2,323 units: in $2019-2,951$ units, and in $2020-3,579$ units. In comparison with actual figures in 2017 , the projected growth in 2020 will be $88 \%$ (Fig. 3).

To ensure the development of renewable energy and to provide certain guarantees to investors and to encourage the development of the latest technologies and innovations in this area, the Cabinet of Ministers of Ukraine by its Order No 791-p of 3 September 2014, approved the plan of measures for the implementation of the Directive 2009/28/EU of the European Parliament and of the Council. By order of 1 October 2014 No 902-p, the National Renewable Energy Action Plan for the period up to 2020 was approved, which envisages an increase of installed elec- tric power capacities of renewable energy to 10,900 MW and bring the production of 'green' electricity to 26 billion $\mathrm{kWh}$ per year in 2020 (State Energy Efficiency Ukraine, 2014).

The potential of solar energy development is provided by its own scientific and industrial base, design bureaus that design solar collectors, mono- and polysilicon production, nanotechnology, the availability of necessary metal products, etc. Photovoltaic projects are being actively implemented in Ukraine since 2010. The benefits of solar power are the universality and inexhaustibility of the energy source (Agroexpert, 2016).

The unfavourable investment climate in the country's economy creates barriers for the development of innovative technologies, including of renewable energy. For the sustainable development of solar energy in Ukraine, nationwide energy sector support and stimulation programs are needed.

\section{CONCLUSIONS}

Among the renewable energy sources in Ukraine, solar power generation and solar power plants are growing at the fastest pace. The research carried out by the authors showed that the dynamics of the

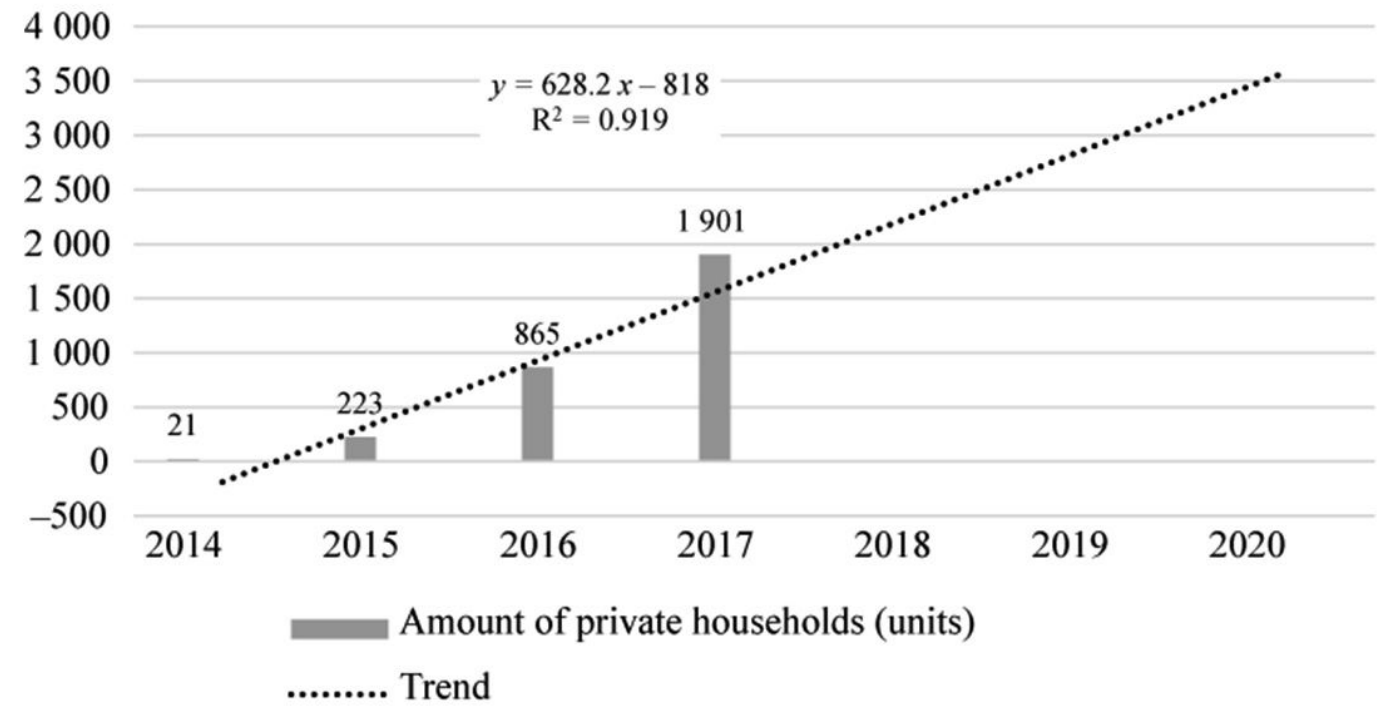

Figure 3. Forecasting the development of the installation of solar power plants by private households Source: calculated by the author. 
growth of the number of installed solar power plants by households, with the purpose of self-generation of electricity for own needs, remains stable.

According to the results of the analysis, the authors calculated the prospect of installing solar power plants by private households by 2020 . In order to implement solar energy development plans in Ukraine, there is a scientific base with a sufficiently large number of institutes, specialists, and experience in implementing modern technologies into practice. An important factor is also taking into account foreign experience in this field.

\section{REFERENCES}

1. Agroexpert (2016). Potential of renewable energy sources in Ukraine. Retrieved from: https://www.agroexpert. $\mathrm{ua} / \mathrm{ru} /$ potencial-vidnovluvanih-dzerel-energii-v-ukraini [Accessed 12.12.2016].

2. Chornyy, R. et al. (2016). Development and implementation of solar energy in households in Ukraine. International Scientific Journal. Internauka, 10 (20), Vol. 2, pp. 66-71.

3. Government portal (2018). Solar energy in Ukraine is developing rapidly: it is proved by business and even by private households. Retrieved from: https://www.kmu. gov.ua/ua/news/sonyachna-energetika-v-ukrayini-zhvavo-rozvivayetsya-ce-dovodyat-biznes-ta-navit-privatni-domogospodarstva\# [Accessed 05.05.2018].
4. Kucher, O. et al. (2017). Marketing Strategies and Prognoses of Development of the Renewable Energy Market in Ukraine. Scientific Achievements in Agricultural Engineering Agronomy and Veterinary Medicine. Traicon.

5. Law of Ukraine on Amendments to Some Laws of Ukraine on Ensuring Competitive Conditions for the Production of Electricity from Alternative Energy Sources. Laws of Ukraine of 04.06.2015, No 514-19.

6. Odintsova, U. (2014). Some methodological foundations of bioeconomics. Issues of Economics and Law, 4, pp. 63-65.

7. Plachkov, I. et al. (2013). Electricity and environmental protection. Functioning of energy is in the modern world. Power Engineering: History. Present and Future. Kyiv.

8. Prel.prom (2017). In Ukraine, the total power of SES will exceed 1000 MW: by the end. Retrieved from: https://prel.prom.ua/n231669-ukrayini-zagalna-potuzhnist.html [Accessed 25.09.2017].

9. State Energy Efficiency of Ukraine (n.d.). In 2017 solar power plants installed twice times more. Retrieved from: http://saee.gov.ua/uk/news/2170 [Accessed 03.02.2018].

10. State Energy Efficiency of Ukraine (n.d.). Energy of the Sun Retrieved from: saee.gov.ua/uk/ae/sunenergy [Accessed 01.10.2014].

11. State Energy Efficiency of Ukraine (n.d.). Renewable energy. Retrieved from: http://saee.gov.ua/uk/activity/ plany-rozvytku/vidnovlluvalna-energetyka [Accessed 01.10.2014]. 